\author{
A.B. Temirbolat ${ }^{1}$ iD , M.M. Kozhashev ${ }^{2}$ iD \\ ${ }^{1}$ Al-Farabi Kazakh National University, \\ ${ }^{2}$ Abay Kazakh National Pedagogical University, Kazakhstan, Almaty, \\ e-mail: alua.temirbolat@kaznu.kz,raimbek26@mail.ru,
}

\title{
CATEGORY OF CHRONOTOPE IN ZHAMBYL ZHABAEV'S POETRY
}

In the article the work of Kazakh literature's classic of Zhambyl Zhabaev are considered. The features of his artistic world and the author's concept of being and personality are revealed. The originality of $Z \mathrm{~h}$. Zhabaev, his skill and peculiarities of the approach to depicting reality are conceptualized. The object of research is the spatial-temporal organization of the poet's poems. The role of chronotope's category in the work of Zhambyl Zhabaev is revealed. It is indicated that time and space are not only the basis for building the artistic world, but also contribute to the disclosure of the philosophical-aesthetic views of the poet. Based on the analysis of chronotope's category, the poet's attitude to the phenomena and events, which he describes is determined. In the process of analysis, it is noted that the spatial-temporal continuum of Zh. Zhabaev's works is characterized by complexity and multidimensionality. It is proved that various types of the chronotope are presented in his poetry, which reflect his worldview and attitude. During the study, the features of the functioning of the categories of time and space in the works of Zh. Zhabaev. The versatility of the world depicted in poems, the keen interest of the poet in the soul space of the lyrical hero, is emphasized. The principles of constructing the works of Zhambyl Zhabayev are revealed.

Key words: work, poem, theme, time, space, idea, chronotope, poet.

\author{
А.Б. Темірболат ${ }^{1}$, М.М. Қожашев² \\ 'Ә^-Фараби атындағы Қазақ ұлттық университеті, \\ ${ }^{2}$ Абай атындағы Қазақ ұлттық, педагогикалық университеті, \\ Қазақстан, Алматы қ., e-mail: alua.temirbolat@kaznu.kz, raimbek26@mail.ru
}

Жамбыл Жабаев поэзиясындағы хронотоп категориясы

Мақалада қазақ, әдебиетінің классигі Жамбыл Жабаевтың шығармашылығы қарастырылады. Қаламгердің көркемлік әлемі мен болмыс және жеке тұлғаның авторлық концепциясының ерекшеліктері ашылады. Мақалада Ж. Жабаевтың шығармашылық шеберлігі және ақиқат шындықты бейнелеудегі өзіндік тәсілдері пайымдалады. Зерттеу нысаны ақын өлеңдерінің кеңістіктік-уақыттық континуумы болып табылады. Жамбыл Жабаевтың шығармашылығындағы хронотоп категориясының рөлі ашылады. Уақыт пен кеңістіктің көркемдік әлем құрудың негізі болып қана қоймай, ақынның философиялық-эстетикалық көзқарастарын ашуға ықпал ететіндігі көрсетіледі. Хронотоп категориясының талдауы негізінде ақынның өзі суреттеген құбылыстар мен оқиғаларға қатынасы анықталады. Талдау барысында Ж. Жабаев туындыларының кеңістіктікуақыттық континуумы күрделілігімен, көп өлшемділігімен сипатталатындығы дәлелденеді. Ақынның поэзиясындағы оның дүниені қабылдауы және дүниені сезінуін көрсететін хронотоптың түрлі типтері анықталады. Зерттеу барысында Ж. Жабаев шығармаларындағы уақыт пен кеңістік категорияларының қызмет ету ерекшеліктері қарастырылады. Өлеңдерле бейнеленетін әлемнің көпқырлылығы, ақынның мирикалық кейіпкердің жан кеңістігіне деген қызығушылығы айтылады. Жамбыл Жабаев шығармаларының құру принциптері ашылаАы.

Түйін сөздер: шығарма, өлең, тақырып, уақыт, кеңістік, идея, хронотоп, ақын.

\author{
А.Б. Темирболат ${ }^{1}$, М.М. Кожашев ${ }^{2}$ \\ 'Казахский национальный университет им. аль-Фараби, \\ ${ }^{2}$ Казахский национальный пеАагогический университет им. Абая, \\ Казахстан, г. Алматы, e-mail: alua.temirbolat@kaznu.kz, raimbek26@mail.ru
}

\section{Категория хронотопа в поэзии Жамбыла Жабаева}

В статье рассматривается творчество классика казахской митературы Жамбыла Жабаева. Раскрываются особенности его художественного мира и авторской концепции бытия и личности. Осмысляется самобытность Ж. Жабаева, его мастерство и своеобразие подхода к изображению 
Аействительности. Объектом исследования является пространственно-временная организация стихотворений поэта. Раскрывается роль категории хронотопа в творчестве Жамбыла Жабаева. Указывается, что время и пространство являются не только основой построения хуАожественного мира, но и способствуют раскрытию философско-эстетических взглядов поэта. На основе анализа категории хронотопа определяется отношение поэта к описываемым им явлениям и событиям. В процессе анализа отмечается, что пространственно-временной континуум произведений Ж. Жабаева характеризуется сложностью, многомерностью. Аоказывается, что в его поэзии представлены различные типы хронотопа, которые отражают его мировосприятие и мироощущение. В процессе исследования рассматриваются особенности функционирования категорий времени и пространства в произведениях Ж. Жабаева. Подчеркивается многогранность изображаемого в стихотворениях мира, пристальный интерес поэта к пространству Ауши кирического героя. Раскрываются принципы построения произведений Жамбыла Жабаева.

Кмючевые слова: произведение, стихотворение, время, пространство, идея, хронотоп, поэт.

\section{Introduction}

Zhambyl Zhabaev is the classic of Kazakh literature. His works are widely known to readers. The poetry of Zhambyl Zhabaev is a kind of chronicle of the history of Kazakhstan. On the pages of his works he narrates about the main events taking place in the country, reflects on the present and future of the people. Great attention in his work is paid to universal and eternal problems. Zhambyl Zhabaev talks about happiness, the meaning of life, friendship, the joys of being. Each work of the poet is filled with great love for his native land, imbued with civil and patriotic motives.

The poetry of Zhambyl Zhabaev is characterized by a variety of genres. He wrote lyric, everyday, social-satirical songs, heroic poems and fairy tales ("The Dog of Bay Kadyrbay", "The Black Decree", "The Poem of an Angry Heart", the poems "Utegen Batyr", "Suranshi Batyr", the fairy tale "Khan and akyn", "The Tale of the Lazy Dog" and others).

Zhambyl Zhabaev is a recognized master of the word. On the pages of his works, he managed to create an original and unique world. Ordinary phenomena and things acquire a special colour in his work.

The works of Zhambyl Zhabaev are of great interest to readers, researchers and the public. His literary heritage is regularly discussed at international and national conferences, symposia and forums.

A significant contribution to the study of Zhambyl Zhabaev's work was made by such famous scientists, writers, critics as M. Auezov, R. Rollan, M. Sholokhov, K. Simonov, H. Suyunshaliev, K. Beisembiev, A. Baitanaev, M. Balakaev, B Kenzhebaev, E. Ismailov, M. Zholdasbekov, S. Begalin, S. Sadyrbaev, Zh. Dadebaev, M. Umbetaev, K. Zharmaganbetov, E. Sydykov and others. In their works, they expound his biography, reveal poetic and improvisational skills. "Zhambyl," - writes M. Zholdasbekov, - "was able not only to splendidly compose verses impromptu. But also masterly playing dombra, masterfully performing voluminous epic chants, rehearsing his aitys and parts of other akyns from memory, telling stories, genealogies and fairy tales"( Zholdasbekov M., 1993: 15).

The monograph of E. Ismailov "Akyns" (Ismailov E., 1956) is devoted to the study of the problems of pride and innovation, the influence of oral folklore, and the epic tradition on the poetry of $\mathrm{Zh}$. Zhabaev. Based on a comparative-typological analysis, the researcher reveals the features of the ideological-thematic content of the works of the great akyn, the originality of his artistic world and method.

B. Kenzhebaev (Kenzhebaev B., 1955), H. Suyunshaliev (Suyunshaliev H., 1955) discuss the storytelling and poetic talent of Zhambyl. Based on the analysis of his works, researchers show the versatility of the gift of $Z \mathrm{~h}$. Zhabaev.

The work of M. Silchenko is devoted to the study of the system of images of Zhambyl's poetry. Based on the analysis of accusatory songs of akyn, the researcher reveals the features of his creative method and approach, defines the typical features of the characters of his works (Silchenko M., 1956).

Features of the style and language of Zh. Zhabaev are the subject of analysis in the works of M. Balakaev (Balakaev M., 1948).

The artistic originality of Zhambyl's work, his aesthetic ideals and values are revealed in the works of Zh. Dadebaev. According to the researcher, the distinctive features of akyn's poetic heritage are sincerity, purity of spiritual impulses and thoughts (Dadebaev Zh., 2008: 276).

The book of E. Sydykov "Zhambyl" (Sydykov E., 2015) is devoted to understanding the role of $\mathrm{Zh}$. Zhabaev in the historical-cultural process of Kazakhstan, the significance of his poetic heritage. Describing the life and career of the great akyn, the author reveals the features of the development of 
society in XX century. In the book the problems of continuity of national traditions are examined. Great attention is paid to the refraction of historical events through the prism of the fate and work of the poet.

However, despite such close attention of scientists to the heritage of $\mathrm{Zh}$. Zhabaev, some problems to this day remain insufficiently studied. Among them is the question of the role and function of the category of chronotope in his poetry.

The study of this problem will allow to better comprehend the originality of the artistic world of Zhambyl Zhabaev, to understand the features of his worldview, the concept of being, the construction of works. For the category of chronotope plays a huge role in his poetry.

\section{Experiment}

Time and space are fundamental concepts. They permeate the content and form of the work, determine its integrity. At the level of the chronotope category, the poet's ideas about the world around him are revealed.

Time and space contribute to understanding the sequence and relationship of depicted events. The study of these categories allows you to more deeply comprehend the mental state of the lyrical heroes, the changes that occur in their consciousness and sensual world in the process of their perception of the phenomena of reality.

At the chronotope's level, the poet's mentality, his aesthetic ideals and values are reflected. Through time and space, the problem of continuity of generations is comprehended.

Accordingly, to study the category of chronotope in Zhambyl poetry, historical-functional, comparative-typological, psychological methods, complex approach were used, which allowed, firstly, to reveal the nature of poetic works; secondly, to study the features of the functioning of the category of chronotope; thirdly, to understand the author's perception of time and space. Their application contributed to obtaining a holistic view of the organization of the artistic world of poems of Zh. Zhabaev.

The historical-functional method allowed to identify the originality of the literary heritage of the poet. He contributed to the understanding of the connection of his works with the events of reality.

The comparative-typological method was used to comprehend the patterns observed in the poetry of $\mathrm{Zh}$. Zhabaev. As a result of a comparative study of his poems, the features of their ideological-thematic content, spatial-temporal organization were established.
The psychological method contributed to the disclosure of the inner world of lyrical heroes, understanding of their experiences, doubts, feelings. Based on its application, features of the author's concept of personality were revealed, the poet's attitude to the surrounding reality was studied.

The complex approach allowed to explore the spatial-temporal continuum of Zhambyl's poems. As a result of its application, the essence of the author's concept of being, the system of his aesthetic views and spiritual values, the peculiarities of the relationship of the depicted images and events were revealed.

\section{Results and discussions}

The works of Zhambyl Zhabaev are imbued with images with spatial and temporal content. The poet often puts these categories in the title of his poems. An example of this is the works "Alatau", "In the Mountains", "The Road to the Steppes", "On Dzhailau", "I reached the top of the mountain," "Spring", "Running of Time", "I am a Centennial Poplar", "Old Age", "Song of the Summer". Each of them is associated with a specific event and period in the life of the poet. So, in the poem "Alatau" (1937), the beauty and grandeur of the Zaili mountains are glorified. The poet very picturesque recreates the pictures of nature.

The chronotope of this work characterizes by specificity. In the poem the temporal and spatial boundaries of the depicted world are clearly indicated. The events described by the author unfold in the summer in the mountains located near Almaty.

The time-space of the poem spans several plans. Firstly, the chronotope of nature. The author praises the beauty and grandeur of Alatau mountains. Secondly, the time-space of Almaty city. The author notes the beauty of the capital, its location. Thirdly, the chronotope of the poet Zhambyl Zhabaev. The author describes himself, his house. Fourth, the time-space of a foreign country located behind Alatau Range. The author notes that there is a war going on.

The combination of several spatial-temporal plans allows, on the one hand, to understand the author's concept of being, the features of his worldview and attitude; on the other, to see the world in all its versatility, complexity and originality.

The poem contains a description of the historical epoch in which Zhambyl Zhabaev lived and worked. So, in the last three stanzas, the poet says: 
"Alatau is rich! In a turban of ice

It didn't give his wealth to his enemies,

Lakes and ores, gardens and dzhailau

It gave the heroes of struggle and labor.

And there, beyond the ridge Alatau, is visible

Under a cloudy sky a foreign country

Where the wind walks through clay fanzas

And war is smoking with warm blood.

Dzhambul from a height looks around a ravine -

Is there a cunning embittered enemy hidden there?

Over the white felt yurt of Jambul

Like a flame, a poppy flag flutters!"

(Dzhabaev D., 1980: 222-223).

The mention of the historical epoch goes in some contrast with the description of the mountains. Such a construction reinforces the impression, which the work makes on the reader. On the one hand, the contrast emphasizes the beauty and grandeur of the mountains, on the other, it shows the strength, power, prosperity of the country in which the poet lives.

Moreover, the mountains are the border between the two worlds. They share different states with different social structure and political system.

The inclusion of a historical chronotope in a poem helps, firstly, to expand the boundaries of the world depicted by the poet; secondly, deepening the psychologism and dramatism of the work; thirdly, the disclosure of the realism of the described events.

By comparing the two countries, the poet touches upon the theme of war and peace. Thus, he goes beyond the real chronotope, rising to universal problems. Such approach shows the complexity, inconsistency of the world.

In the poem the problem of alienation is raised. The poet draws a clear border between the two worlds. The first is his homeland, blooming and beautiful. It is characterized by the breadth, infinity of spatial-temporal boundaries. The second world is a state located behind a ridge where war is going on. Zhambyl Zhabaev calls it a stranger, thereby showing that it is completely unlike his country. This world is characterized by the closeness of the chronotope.

In the work the upper and lower worlds are described. Showing the beauty of the mountains from the height of an eagle's flight and gardens spread on their slopes, the author emphasizes the harmony of life, the unity and integrity of nature's chronotope.

The world of the poet himself is connected with the upper world. Describing himself, the author says: "Dzhambul looks over a ravine from above" (Dzhabaev D., 1980: 223).
The crossing of the chronotope of mountains and the chronotope of the poet, on the one hand, shows their unity and interconnection; on the other, the aspiration of the poet and the country, in which he lives, upward, into the future.

In the poem the social, cultural-historical and psychological chronotopes are clearly traced. At the first level, the features of the existence of two different states are revealed. The cultural-historical chronotope reflects the features of the depicted epoch. Psychological time-space shows the inner world of the poet, his state of mind. It reflects the feelings, thoughts of the author, his attitude to his motherland.

Distinctive features of the psychological chronotope are joy, admiration, faith, pride, which fill the poet's soul space, the dynamism of time. The author rejoices, which is reflected in the level of description of the world around him. The chronotope of nature is characterized by colorfulness, polyphony. It is filled with sounds - the sound of a waterfall, the rustling of trees. Describing the world around him, the poet uses adjectives of the type: "juicy", "azure", "purple", "rainbow", "yellow", "turquoise", "green", the verbs "rattles", "boils", "plunges", "sing", "swirl", "grow oil", "shine". He broadly includes metaphors, comparisons. For example, mountain ranges are associated with roan horses, meadows covered with greenery resemble an emerald, wild strawberries cover the earth like a carpet, fish floating in the water flicker like silver.

At the level of the poet's image, the chronotopes of two worlds intersect:

\footnotetext{
"Dzhambul from a height inspects a ravine -

Is there a cunning embittered enemy hidden there?

Over the white felt yurt of Dzhambul,

Like a flame, a poppy flag flutters!"

(Dzhabaev D., 1980: 223).
}

These lines contain a contrast and are filled with deep meaning. In them there is a clear opposition "up-and-down".

Dzhambul is associated with an eagle soaring above the mountains. He is a representative of the upper, upward, into the future of a world in which spiritual values dominate. The ravine is a symbol of the hostile, lower world in which war is going on.

The white yurt is the embodiment of the image of the motherland. Its color shows the beauty, the greatness of the country, in which the poet lives, the purity of the ideals and thoughts of the people. A flag resembling a flame is a symbol of people's spiritual aspirations. 
The poem is permeated with a motive of mystery. The flickering of snow on the tops of the mountains, shaggy clouds that swirl and golden at sunset create an atmosphere of mystery. According to the author, they "guard the secrets of pearl peaks".

A peculiar hymn to heat and the sun is the poem "Song of the Summer" (1937). In it the nature and condition of people at a particular time of the year are described. In the work the temporal and spatial boundaries of the depicted world are clearly traced. The events described by the author unfold in July. The place of action is the steppe and Kazakh village in which the poet lives, spread in it.

The spatial-temporal continuum of the poem includes several plans. Firstly, the chronotope of nature. The author describes the changes taking place in it. He notes that in summer "grasses rustle in the steppe", "rays pour from the sky", "ponds are full of birds", and "fruits are poured with juice". Secondly, time is the space of Kazakh village in which the poet lives. According to the author, "the youth is having fun", songs and laughter are distributed everywhere. Thirdly, the chronotope of the poet himself, at the level of which his inner world is revealed.

It should be noted that the spatial-temporal boundaries of the village are moved apart in the poem to the scale of the country. Describing the beauty of his motherland, the poet goes into to deep generalizations, showing the power and greatness of the state in which he lives:

\footnotetext{
"My Motherland is an eternal garden,

Tulips bloomed

And eleven sister countries,

Like birds closed their wings.

And eleven countries is a garden,

And it's free for the people in it" (Dzhabaev D., 1980: 221).
}

The extension of the spatial-temporal boundaries is observed at the level of the individual time-space of the poet himself. Recreating the pictures of nature and life of his native village, the author uses the pronoun "mine" (for example: "saddle my horse", "my youth has fun", "my motherland", "my people", "singing, my sea, burles", "my fine summer"," the garden of my country in July"). Describing the country in which he lives, he says "we". Thus, the author shows the inextricable connection of his fate and the fate of Kazakh people with the life of the whole country. At this level, his private chronotope, on the one hand, incorporates the chronotopes of nature, the inhabitants of the village, and on the other, merges with the chronotope of the state.
The image of the garden is noteworthy in the poem. The boundaries of its chronotope constantly vary and are conditional. The image of the garden is connected, firstly, with the poet's motherland ("My Motherland is an eternal garden", "The july garden of my country"); secondly, with eleven countries that are part of a single state ("And eleven countries are a garden"); thirdly, with a specific time period, season of the year ("july garden"); fourthly, with eternity ("eternal garden").

The multidimensionality of the chronotope of this image is determined by the peculiarities of the poet's worldview. In his understanding and perception, the blooming summer garden is a symbol of happiness, prosperity.

The poem contains appeals. Describing the summer, the author seems to enter into dialogue with the world around him. The work begins with the words: "Saddle my horse". Describing the country in which he lives, he turns to his soul ("Young, soul, young!"), to the blacksmith ("Above the hammer, the blacksmith, uplift"), to the plowman ("Go deeper, plowman, explode strata"), to the sea ("Foam, my sea, burles!"). Such a construction of the work helps to reduce the spatial-temporal distance between the author and the reality depicted by him.

In the work social, cultural-historical and psychological chronotopes are reflected. At the level of first from them, the features of the life of the inhabitants of the village, youth are revealed. A social chronotope allows you to track changes in society, in the minds of people:

\footnotetext{
"The eyes of people have become clear,

The bowl is full - whatever the house

And it is not visible grief around"

(Dzhabaev D., 1980: 220-221).
}

The cultural-historical chronotope reflects the features of the life of Kazakh people at the time of the year depicted by the author. Its distinguishing features are songs, games, fun of youth.

At the level of the social, cultural-historical chronotopes of the poem, the achievements of the country are revealed - the construction of railways, mining, and the development of technology.

The psychological chronotope shows the inner world of the persons depicted in the work. Its distinctive features in the poem are joy, liveliness, filling the space of the soul of people, the dynamism of the flow of time.

The biological chronotope of the poem reflects the unity of man and nature. At its level, the changes 
occurring in the life of people and the world around them are revealed.

The poem repeatedly uses words such as "greatness", "open space", "distance", "unlimited". They reflect the power of the country in which the poet lives and works.

The finale of the work is noteworthy. It ends with an exclamation and an ellipsis:

"My country's July garden

It will bloom even more wonderful!.."

(Dzhabaev D., 1980: 221).

Such a finale symbolizes the poet's hope for even greater transformations in the country and its wonderful future. He believes that civilization and culture will continue to develop, thereby increasing the well-being of the people.

The transformation of nature is described in the poem "Spring" (1938). The author shows how the world is changing at this time of the year. The work notes the influence of spring on the mental state of people:

"Spring spilled over the steppe, like a river,

Crane trail flying clouds.

The earth turns green, bright, wide.

Everything blooms, and the dawn is like the blossoming of a flower.

Blossom, just stick it in a pile of sand.

Careless people, labor became joy"

(Dzhabaev D., 1980: 292).

The spatial-temporal continuum of the poem has quite clear boundaries. The events depicted by the author unfold in the spring. The author indicates the approximate age of the poet ("Dzhambul lived a lot, one hundred and one spring"), which allows to determine the chronological framework. The scene is dzhailau.

The events described by the author unfold in several spatial-temporal plans. The poem recreates the image of nature. The author shows the changes occurring in it with the advent of spring.

The chronotope of nature combines with the chronotope of humans. The poem contains a description of life, the mood of the inhabitants of the village. The author constantly draws parallels between the natural world and the human world. So, he compares the swell of the lake with kaimak foam, calls himself a pacifier, mentioning the game of dombra, says that "a bird flies through it - not a hand".
Great attention in the poem is paid to the inner world of the poet himself. His mood is revealed, emotions that permeate his soul are transmitted.

Spring, according to the poet, being a symbol of rebirth, has a positive effect on a person, on his individual time-space. Under its influence, it is transformed externally and internally, as evidenced by the following lines:

\footnotetext{
"Younger, rejoice in the sunny spring,

One hundred years - one hundred pounds - easy for an old man,

Sixty-two veins poured blood

A bird flies over the dombra - not a hand"

(Dzhabaev D., 1980: 292).
}

The chronotope of the work is characterized by complexity. The author is constantly changing his spatial-temporal position. Either he presents the events in the third person as an outside observer, as if he appeals to the people and the reader using the verbs of the second person, then he describes his own state of mind and the changes that occur with him. As a result, an integral picture of the depicted reality is formed.

The theme is music. It is revealed at the level of images of dombra and song.

Appeal to this topic is determined by the poet's desire to show the positive impact of spring on man, on the world. This time of year is so inspiring that it contributes to the birth of new songs, the transformation of the space of the soul of people, the expansion of the boundaries of their individual chronotopes.

Reflections about time filled the poem "In the Mountains" (1940). The author describes his age and related changes. According to him, he became old, his eyes were dull, and he cannot climb to the top of the mountain.

The chronotope of this work covers two planes the world of the poet and the world of nature. Talking about old age, the author describes the mountains. Characterizing himself, he says that he has "falcon impulse" cooled down, and in his ears, "the conversation speaks like an aryk".

In the poem, there is a contrast between the past and the present:

\footnotetext{
"On the steep slopes, as in the past summers, I don't walk. For my wanderings I am not saddling a horse, as before" (Dzhabaev D., 1980: 315).
}

The author's concept of time is revealed in the work. The poet describes its flow. In his opinion, "the years have passed". Thus, the poet shows the swiftness, the irreversibility of time. 
It is interesting that the author correlates his image with this category. Zhambyl Zhabaev calls himself "the same age as the century". At this level, the author's idea of the significance of the category of time in human life is revealed.

The biological chronotope is clearly presented in the work. It reflects the age characteristics of the poet, the changes that occurred with him with the onset of old age.

The title of the poem is noteworthy. It carries a deep meaning. The image of mountains shows the author's conversion into the space of his past and present.

The work contains ellipses. The poet puts them, describing his state. Thus, he emphasizes the uncertainty of his own future.

The poem "Old Age" (1941) is close in its content and tone to this work. It is built in the form of appeal. The poet leads a peculiar conversation with old age. He asks it questions, reproaches it that it changed his appearance, took away his strength.

Old age materializes in a poem. According to the author, it pushes him, sits on him. Such a construction contributes to a deeper comprehension of the poet's inner world, the opening of the space of his soul. The author conveys in detail his attitude to old age.

In the poem parallels between the world of people and the world of nature are drew:

\section{"Iron shovel in chalk solution - \\ That's the beard of Dzhambul on the centuries-old slope" (Dzhabaev D., 1980: 318).}

These lines express the idea of the unity of the three chronotopes. Firstly, the connection of individual times and spaces of the poet and the mountains surrounding him is revealed. Secondly, the unity of the chronotopes of human being and the individual is emphasized. Thirdly, at the level of the image of the poet, the intersection of data of individual times and spaces occurs. For the life of Zhambyl, on the one hand, is inextricably linked with everyday life, daily labor, and on the other, with the world of nature surrounding him.

The theme of old age is central in the poem "I reached, walking, the tops of the mountain" (1941). It is permeated by the poet's thoughts about his present and future. The author describes in detail the changes that have occurred to him, and his attitude to old age.

The spatial-temporal continuum of the poem includes several plans. The work intersects the past, present and future, the world of nature, the world of people and the world of art. These spatial-temporal measurements are combined at the poet's chronotope level. Talking about his state, he draws parallels with nature and with the image of dombra:

\footnotetext{
"I reached, walking, the tops of the mountain, And the age is endless, like a dombra song...

Legs diverge like strings, tremble

I can't stand, my legs are old"

(Dzhabaev D., 1980: 318).
}

The mountains in this case symbolize the path of man, his aspiration upward, into the future, towards the world of dreams, towards his goals and ideals.

The song, according to the author, is eternal as time. It has been heard for centuries, transmitted from generation to generation.

The poet's achievement of the top of the mountain and the mention of the strings of the dombra when creating his own portrait shows the completion of his life and the connection of his private chronotope with eternity.

An interesting comparison with the wagon ("I am like a dilapidated wagon"). It gives expressiveness to the image of the poet, enhances the sensation of the passage of time and its impact on the material world and man.

This comparison contains a deep symbolic meaning. Home is the guardian of human life. It protects him from the effects of the outside world. A dilapidated home reflects the extinction of life.

Describing old age, the poet appeals to the doctor. He asks the doctor for an answer to his question. Thus, the author, on the one hand, emphasizes the impotence of man before the passage of time; on the other, it touches on the eternal problem of life and death.

In the work the inner world of the poet is revealed. It is permeated with rhetorical questions and exclamations that reflect his mental state, thirst for life and regret for the new age.

Accordingly, the poem presents two types of chronotope - biological and psychological. The first reflects the age-related changes of the poet at the level of his appearance and physical parameters. The second reveals the experiences of the poet.

The idea of the uncertainty of the future is carried out in the work. The poem ends with the question: "Well ahead?". Such a finale enhances the effect of the work on the reader, forcing him to think about the meaning of life, its finiteness, the passage of time and the future. 


\section{Conclusion}

Thus, the distinctive features of the chronotope of Zhambyl Zhabaev's poems are multidimensionality, complexity. In his works, the life of the Kazakh people is described, the change of seasons is shown, historical events and social transformations are characterized.

The poems of Zh. Zhabaev are characterized by polyphony. They are filled with the voices of people, the sounds of nature.
The spatial-temporal continuum of his works covers several plans - real, historical. The author mentions the past, present, future. His poems contain appeals, rhetorical questions and exclamations. The world of people is described in unity with the world of nature. In the poems of Zhambyl Zhabaev various types of chronotopes are depicted - social, cultural-historical, psychological, biological, contributing to the creation of a holistic picture of being.

\section{References}

Balakaev M. (1948) Zhambyl olenderinin tili. Khalyk mugalimi. [The language of Zhambyl’s poems]. National teacher. № 9. P. 23-27. (in Kazakh)

Dadebaev Zh.D. (2008) Zhambyl. Dadebaev Zh.D. Tandamaly shygarmalar. Eki tomdyk. Vol. 1. [Featured Works] Алматы: Oner. P. 252-282. (in Kazakh)

Dzhabaev D. (1980) Izbrannye proizvedeniya. [Featured Works]. Alma-Ata: Zhazushy, 400 p. (in Russian)

Ismailov E. (1956) Akyndar. [Poets]. Almaty: Korkem adebiet, 340 p. (in Kazakh)

Kenzhebaev B. (1955) Zhambyl Zhabaev Kazakh halkynyn zhyrshysy. [Zhambyl Zhabaev is the storyteller of Kazakh peoples]. Almaty: Kazakh state publishing house, 32 p. (in Kazakh)

Silchenko M.S. (1956) O tipichnosty obrazov-personazhei v oblichitelnyh pesnyah Dzhambula dosovetskogo perioda. V kn.: Tvorshestvo Dzhambula. [On the typical character images in accusatory songs of Jambul of the pre-Soviet period]. Work of Dzambul. Alma-Ata: SA of KazSSR. P. 15-23. (in Russian)

Suyishaliev H. (1955) Zhambyl Zhabaev Kazakh halkynyn uly akyny. [Zhambyl Zhabaev is the great poet of Kazakh peoples]. Almaty, 42 p. (in Kazakh)

Sydykov E.B. (2015) Zhambyl. [Zhambyl]. Moscow: Artistic literature, 367 p. (in Russian)

Zholdasbekov M. (1993) Zhambyl i ego poeticheskie tradicii: avtoreferat dissertacii doktora philolog. Nauk: 10.01.02. [Zhambyl and his poetical traditions]. Abstract of the dissertation of a doctor of philological sciences: 10.01.02. Bishkek: KSU, 39 p. (in Russian)

\section{Литература}

Жолдасбеков М. Жамбыл и его поэтические традиции: автореферат диссертации доктора филолог. наук: 10.01.02. Бишкек: КГУ, 1993. - 39 с.

Исмаилов Е. Ақындар. - Алматы: Көркем әдебиет, 1956. - 340 б.

Кенжебаев Б. Жамбыл Жабаев - қазақ халқының жыршысы. - Алматы: Қазақ мемлекет баспасы, 1955. - 32 б.

Сүйіншалиев Х. Жамбыл Жабаев - қазақ халқының ұлы ақыны. - Алматы: Қазақ мемлекет баспасы, 1955. - 42 б.

Сильченко М.С. О типичности образов-персонажей в обличительных песнях Джамбула досоветского периода // В кн.: Творчество Джамбула / Ред. Смирнова Н.С. - Алма-Ата: АН КазССР, 1956. - С. 15-23, 123 с.

Балақаев М. Жамбыл өлеңдерінің тілі // Халық мұғалімі. - 1948. - № 9. - Б. 23-27.

Дәдебаев Ж.Д. Жамбыл. // Дәдебаев Ж.Д. Тандамалы шығармалар. Екі томдық. 1-том. - Алматы: Өнер, 2008. -352 б. - Б. 252-282.

Сыдыков Е.Б. Жамбыл. - М.: Художественная литература, 2015. - 367 с.

Джабаев Д. Избранные произведения. - Алма-Ата: Жазушы, 1980. - 400 с. 